\title{
SOIL PROTECTION STUDY THROUGH THE APPLICATION OF COMPLEX METHODS FOR SUSTAINABLE MANAGEMENT OF THE SOYBEAN AGROSYSTEM
}

\author{
Felicia Chețan ${ }^{1 *}$, Loredana Suciu ${ }^{1,2}$, Cornel Chețan ${ }^{1}$, Adina Tărău ${ }^{l}$, Ioana Crişan ${ }^{l}$, Felicia \\ Mureşanu ${ }^{1}$ \\ ${ }^{1}$ Agricultural Research and Development Station Turda, Romania \\ ${ }^{2}$ University of Agricultural Sciences and Veterinary Medicine, Faculty of Agriculture, Cluj- \\ Napoca, Romania
}

\author{
*Corresponding author: \\ Agricultural Research and Development Station Turda \\ 27 Agriculturii Street, 401100, Turda, Cluj, Romania \\ Tel: $+40264311680(1)$ \\ Fax: +40264311792 \\ E-mail:felice_fely@yahoo.com
}

http://www.doi.org/10.54574/RJPP.13.10

\begin{abstract}
The degradation of natural soil fertility is caused by practicing the classic tillage system (ploughing with the furrow return) and using high doses of chemical fertilizers. It is necessary to adopt soil tillage techniques that aim to preserve and improve soil fertility without decrease production. In Romania, soybean crop, could be an economic boost for the agriculture sector because it reduces the costs required for the procurement of vegetable protein needed for the livestock and food sector, soybeans being a plant that fixes nitrogen from various sources (precipitation, activity of Bradyrhizobium japonicum bacteria, humus mineralization and residual nitrogen). From the research conducted between 2018-2020 at ARDS Turda, regarding the soybean root nodules cultivated in four tillage systems (CS - plough, MC - chisel, MD - disk and NT- direct sowing) with the technology specific to each system, the results indicate that in a conservative system the soybeans yield correlates positively with the number and weight of nodules formed. Organo-mineral fertilization (green fertilizer - autumn rape + gulle manure $+\mathrm{N}_{40} \mathrm{P}_{40}$ ) contributes significantly positively to the number and the weight of nodules and increases the yield. As an alternative to the CS, soybean can be cultivated in a minimum tillage system (MC), the yield difference compared to the classical system (plough) being insignificant, just $38 \mathrm{~kg}$. The pedo-climatic conditions of the experimental area it is favourable for this crop and for the fixation of atmospheric nitrogen, without requiring high doses of mineral fertilizers.
\end{abstract}

Key words: soybean, tillage system, nodules, yield

\section{INTRODUCTION}

As a basic work, the ploughing followed by seedbed preparation and the maintenance agricultural techniques specific to the classical tillage system involve an intense traffic of machines, which in time lead to soil compaction (increases the bulk density, decreases the total porosity and hydraulic conductivity, changes the regime aero-hydric, etc.). As a result of soil compaction, the negative effect on agricultural crop is reflected by reducing the production potential (Grigore et al., 2019; Rusu \& Guş, 2007; Marchenko et al, 2009). Alternative minimum cultivation and no cultivation systems involve reduced intervention on the soil, keeping plant debris at the soil surface by at least $50-60 \%$ performing the role of soilprotecting mulch. Soil is thus protected from surface erosion, soil aggregates are stabilized, organic matter and fertility levels will increase, soil compaction and decrease in $\mathrm{CO}_{2}$ emissions, increased biodiversity (Pisante \& Stagari, 2011; Marin et al., 2015; Sabo et al., 2007; Topa et al., 2012). Vegetable residues left on the soil's surface protect it and, under the action of microorganisms and macroorganisms in the process of transformation, contribute to the improvement of soil structure (Ulrich et al., 2006; Wozniak et al., 2014). 
Choosing the optimal technological variant must take into account the soil's properties: texture, humidity, soil exposure, macro and microclimate, humus content, etc., but also the climatic conditions of the agricultural year and the technological capacity to capitalize on these resources (Stefănic et al., 1997; Szajdak \& Rusu, 2016).

In the Transylvanian Plain there is an interaction of a large number of limiting factors for agricultural technologies, two of which show a dominant action. The first is the thermal factor with low temperature level and with large temporal variations and the second is the hilly orography of the land with numerous soils degraded by erosion (Rusu et al., 2009; 2014; Cheţan \& Cheţan, 2014; Cheţan et al., 2019). Recently, there has been a slight increase in average annual temperatures, as well as a high fluctuation in the distribution of rainfall (Ignea, 2017).

The particular importance of soybean comes from its multiple usages both in the alimentation of people (oil, the mature beans and the green hulls are used in various food recipes), (Subramanian \& Smith, 2013; Cvijanovic \& Cvijanovic, 1988), and in the feeding of animals as well as in industry (oils for painting, the production of plastic mass, the preparation of margarine), and it is also used in the regeneration of the physical properties of the soil due to the symbiosis which is installed between the radicular system and the Bradyrhizobium japonicum bacteria, this symbiosis resulting in the development of special formations (nodules) for the function of fixing atmospheric nitrogen for the benefit of the plant (Stevanović et al., 2016; Popović et al., 2016, 2018). Keyser \& Li (1992) mentions that „the soybean-Bradyrhizobium symbiosis can fix about $300 \mathrm{~kg} \mathrm{~N} / \mathrm{ha}$ under good conditions”. It is known that soil acidity $(\mathrm{pH})$ affects nitrogen fixation, a $\mathrm{pH}$ of less than 6.0 decreases the production and number of root nodules of legumes (Guş et al., 2004). If there are colonies of Rhizobium in the soil, that cause the formation of nodules on the roots of the silk, plants are able to use atmospheric nitrogen, usually unable to fully secure their atmospheric nitrogen, therefore some must be obtained from the soil (through applied mineral fertilizers). Of the total nitrogen needed for soybeans, 70\% are provided symbiotically (Vidican et al., 2013; Li et al., 2020). After the soy crop, the need for nitrogen fertilizers is greatly reduced, and against the background of this culture increases the efficiency of phosphate and potash fertilizers with an economic and agrotechnical efficiency (Höflich et al., 1999; Peoples et al., 2009; Cheţan \& Chețan, 2014).

New variants of soil cultural technologies were studied in order to reduce the negative impact of drought.

The paper presents the results of research conducted during 2018-2020, regarding the root nodules formation and the soybean yield, by applying different tillage systems, under the conditions of the Agricultural Research and Development Station Turda.

\section{MATERIAL AND METHODS}

The experiment has been conducted on a phaeozem argic soil type (SRTS 2012) in Transylvania Plain, with average multiannual rainfall of $531.4 \mathrm{~mm}$ and an average multiannual temperature of $9.2^{\circ} \mathrm{C}$ (for 63 years). The experimental field was placed on a phaeozem argic soil type (SRTS, 2012), having the following properties (MESP, 1987): neutral $\mathrm{pH}$ (7.2), mobile phosphorus $4.1 \% \mathrm{mg} \mathrm{P}_{2} \mathrm{O}_{5} / 100 \mathrm{~g}$ soil, potassium $29 \mathrm{mg} \mathrm{K}_{2} \mathrm{O} / 100 \mathrm{~g}$ soil and humus content $3.2 \%$. The experiment being included in a crop rotation of 3 years: soybean - winter wheat-maize. The biological material chosen for this trial was represented by the soybean Teo TD variety.

The experimental factors were the following: factor A - tillage system with four graduations: a classic with plow (CS), a 2 minimum tillage with chisel (MC), a 3 minimum 
tillage with heavy disk (MD), a 4 direct sowing - no-tillage (NT); factor B - fertilization with four graduation: $b_{1} \mathrm{~N}_{40} \mathrm{P}_{40}$ at sowing, $b_{2}$ gulle manure 5 tons/ha before sowing $+\mathrm{N}_{40} \mathrm{P}_{40}$ at sowing, $b_{3}$ green fertilizer (autumn rape) $+\mathrm{N}_{40} \mathrm{P}_{40}$ at sowing, $\mathrm{b}_{4}$ green fertilizer (autumn rape) + gulle manure 10 tons/ha $+\mathrm{N}_{40} \mathrm{P}_{40}$ at sowing; factor $\mathrm{C}$ - agricultural year with three graduations: $\mathrm{c}_{1} 2018, \mathrm{c}_{2} 2019, \mathrm{c}_{3} 2020$.

The sowing was performed with the Directa 400 machine (at sowing was applied the fertilizer $\mathrm{N}_{40} \mathrm{P}_{40} \mathrm{~K}_{0}$ active substance/ha, avoiding repeated passes with heavy aggregates on the soil surface), at $18 \mathrm{~cm}$ distance between the rows, the seed introduced at $4 \mathrm{~cm}$ depth, density 45 germinative grains $/ \mathrm{m}^{2}$. Weeds control was performed in two stages, in all variants: preemergence with 0.35 liter/ha product with active ingredient metribuzin $(600 \mathrm{~g} / \mathrm{l})+1.5 \mathrm{liter} / \mathrm{ha}$ product with active ingredient $S$-metolachlor $(960 \mathrm{~g} / \mathrm{l})$; post-emergence with 1.0 liter/ha based on imazamox $(40 \mathrm{~g} / \mathrm{l})+1.0$ liter/ha based on propaquizafop $(100 \mathrm{~g} / \mathrm{l})$, when the soybean had 3 - 4 trifoliate leaves. To control the pest Tetranicus urticae, at the time of reporting, treatment with 0.5 liter/ha insecticide based on fenpyroximate was performed. After harvest, the yield obtained was corrected to $13 \%$ moisture content.

Analysis of root nodules were done at the end of blooming for each experimental variant, on an area of $0.25 \mathrm{~m}^{2}$ (the metric frame), with a spade, without damaging the roots, the plants were extracted together with the volume of soil explored by the root system, from each variant, and the root nodules were counted and weighed. Harvest was performed with the combine for experimental field, each experimental plot being of $28 \mathrm{~m}^{2}$. Soybeans were harvested in the second decade of September in each experimental year. The data was processed in two ways, ANOVA (PoliFact, 2015), and the Fisher's protected least significant difference (LSD) test was used to determine the differences among the means at the 5\%, $1 \%$ and $0.1 \%$ level of significance.

The evolution of climatic conditions at ARDS Turda (Meteorological Station Turda,

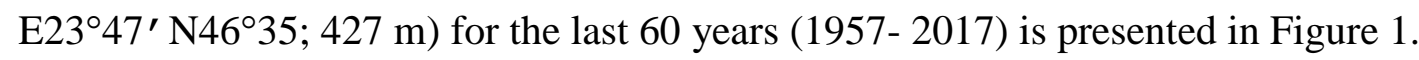

\section{RESULTS AND DISCUSSIONS}

The experiment was conducted on fertile soil, with high susceptibility for compaction induced by large agricultural aggregates and also by working in conditions of high humidity at the $24-25 \%$ soil moisture. The experimental field was characterised by a high clay content (more than 40\%). The multiannual average for 63 years was $9.2^{\circ} \mathrm{C}$, the number of years in which the average annual temperature was below $9^{\circ} \mathrm{C}$ was 25 years, 25 years with a temperature of $9^{\circ} \mathrm{C}$ and above $9^{\circ} \mathrm{C}$ and 13 years in which average annual values of temperatures above $10^{\circ} \mathrm{C}$, especially in recent years (2015-2019). The highest values of average annual temperature are attributed to the year $2019\left(11.4^{\circ} \mathrm{C}\right)$ and the lowest temperature to the 1975 year $\left(7.4^{\circ} \mathrm{C}\right)$. Analyzing the climatic conditions data, it that can be observed that the rainfall regime was uneven and no dominant trend was observed, the multiannual amount for 63 years was $531.4 \mathrm{~mm}$, the number of years in which the precipitations had values below $500 \mathrm{~mm}$ was 24 years, over $500 \mathrm{~mm}$ in 22 years, over 600 $\mathrm{mm}$ were recorded in 13 years and in four years the precipitations had values over $700 \mathrm{~mm}$. The highest rainfall in the entire period was recorded in 2016 with $816.8 \mathrm{~mm}$ and the lowest rainfall was recorded in $2000(259.7 \mathrm{~mm})$. The registered climatic changes (increasing temperatures, decrease in rainfall or non-uniformity of rainfall), as well as the unpredictable ones in the future require the judicious choice of the biological material to be cultivated and the application of some technologies adequate to the new climatic conditions, that why the applied agro-technical measures must be adapted to more oscillating ecological conditions. 


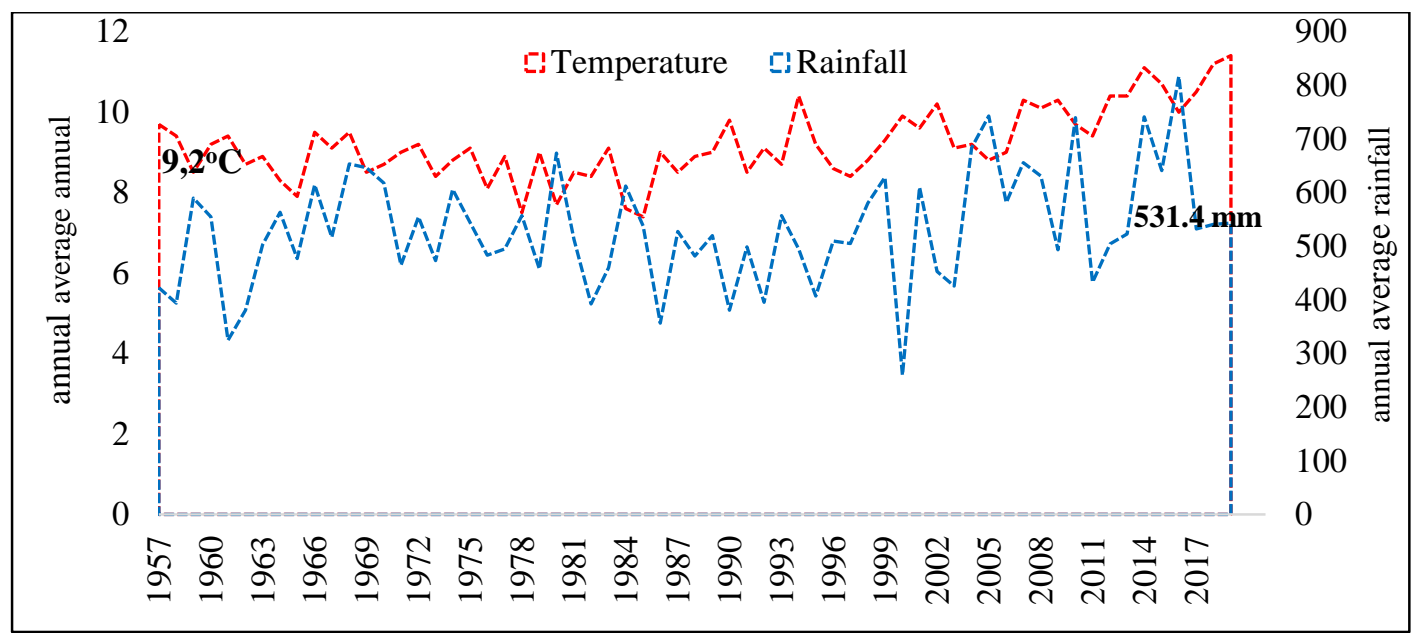

Figure 1. The evolution of the thermal and rainfall regime during 1957-2017

The values of temperature and rainfall, recorded during the April - September for de experimental years (2018-2020) is presented in Table 1 and 2. The six months in the 2018 was warm, the average of temperatures was over multiannual average by $+2.6^{\circ} \mathrm{C}$ and dry with deviation $-40.1 \mathrm{~mm}$. The average temperature recorded in 2019 was higher with $+1.5^{\circ} \mathrm{C}$ comparative with multiannual average $\left(16.2^{\circ} \mathrm{C}\right)$ with a difference of precipitation by +26.9 $\mathrm{mm}$. The year $2020\left(17.1^{\circ} \mathrm{C}\right)$ was closer to the normal multiannual average for this period, but the precipitation exceeded the value of multiannual average with $+55.9 \mathrm{~mm}$.

Table 1. Thermic regime during April - September 2018-2020

\begin{tabular}{|c|c|c|c|c|c|c|c|}
\hline \multirow{2}{*}{ Year } & \multicolumn{6}{|c|}{ Temperature - monthly average $\left({ }^{\circ} \mathrm{C}\right)$} & \multirow{2}{*}{$\begin{array}{c}\text { Average } \\
\text { IV- IX }\end{array}$} \\
\cline { 2 - 7 } & IV & V & VI & VII & VIII & IX & IV.2 \\
\hline Average 63 years & 10.0 & 15.0 & 18.0 & 19.8 & 19.4 & 15.1 & 16.4 \\
\hline 2018 & 15.3 & 18.7 & 19.4 & 20.4 & 22.3 & 16.7 & 18.8 \\
\hline Deviation \pm & +5.3 & +3.7 & +1.4 & +0.6 & +2.9 & +1.6 & +2.6 \\
\hline 2019 & 11.3 & 13.6 & 21.8 & 20.4 & 22.1 & 17.1 & 17.7 \\
\hline Deviation \pm & +1.3 & -1.4 & +3.8 & +0.6 & +2.7 & +2 & +1.5 \\
\hline 2020 & 10.3 & 13.7 & 19.1 & 20.2 & 21.5 & 17.8 & 17.1 \\
\hline Deviation \pm & +0.3 & -1.3 & +1.1 & +0.4 & +2.1 & +2.7 & +0.9 \\
\hline
\end{tabular}

Table 2. Rainfall regime during April - September 2018-2020

\begin{tabular}{|c|c|c|c|c|c|c|c|}
\hline \multirow[t]{2}{*}{ Year } & \multicolumn{6}{|c|}{ Rainfall - monthly amount (mm) } & \multirow{2}{*}{$\begin{array}{l}\text { Amount } \\
\text { IV- IX }\end{array}$} \\
\hline & IV & $\mathrm{V}$ & VI & VII & VIII & IX & \\
\hline Average 63 years & 46.2 & 69.6 & 83.9 & 77.1 & 56.1 & 42.2 & 375.1 \\
\hline 2018 & 26.2 & 56.8 & 98.3 & 85.7 & 38.2 & 29.8 & 335 \\
\hline Deviation \pm & -20 & -12.8 & +14.4 & +8.6 & -17.9 & -12.4 & -40.1 \\
\hline 2019 & 62.6 & 152.4 & 68.8 & 35 & 63.8 & 19.4 & 402 \\
\hline Deviation \pm & +16.4 & +82.8 & -15.1 & -42.1 & +7.7 & -22.8 & +26.9 \\
\hline 2020 & 17.8 & 44.4 & 166.6 & 86.8 & 58 & 57.4 & 431 \\
\hline Deviation \pm & -28.4 & -25.2 & +82.7 & +9.7 & +1.9 & +15.2 & +55.9 \\
\hline
\end{tabular}

Regarding to the three years of experiments, it can be concluded the period was characterized by an uneven distribution of precipitation, there were dry periods of time, with prolonged pedological droughts followed by torrential rains. 
The development of root nodules at soybean differs from the one system to another, from the date presented in Table 3, one can observe the negative influence (distinctly significantly) of the MD and NT in the number and weight nodules, difference between control variant (CS with 98.8 nodules/plant at 3.7 grams/plant) is 12.4 - 20.3 nodules/plant with $1.1-1.0$ grams/plant. The highest value of 119 nodules/plant is recorded at soybean cultivated in the MC (distinctly significantly positive). Regarding of the nodules weight, the beneficial effect of the MC is found in the difference of only 0.4 grams/plant, this difference does not present statistical assurance. The contrary results were obtained by Dogan et al., (2011) following experiments performed in the Cukurova Region in Turkey, they states that the highest average number of nodules was obtained in the no tillage system with sowing directly in the wheat stubble and a smaller number (56 nodules) in the field with mobilization of the soil at $18-20 \mathrm{~cm}$. The number of nodules is distinctly significantly positive influenced by the organo-mineral fertilization (green fertilizer (autumn rape) + gulle 10 tons/ha $+\mathrm{N}_{40} \mathrm{P}_{40}$ ) influence given by the value of number nodules differences (21.7 nodules) and influenced very significantly positive the weight of nodules with difference 0.6 gram/plant compared to the classical system (CS) control. The fertilizing variant with green fertilizer (autumn rape) + $\mathrm{N}_{40} \mathrm{P}_{40}$ did not influenced significantly the number of nodules, but presented significantly positive of the weight of nodules, difference between control variant being 0.4 grams/plant. Referring to the average of the three years considered control (95.5 nodules with 3.1 grams) the root nodules is not influenced significantly by the year factor in this case.

As can be seen from Table 4, the highest number of nodules formed is reflected on yield in the CS (2656 kg/ha) and MC (2618 kg/ha) and less nodules in lowest yield in the MD $(2402 \mathrm{~kg} / \mathrm{ha})$ and NT $(2314 \mathrm{~kg} / \mathrm{ha})$. It seems that the Teo TD variety is pretentious to the unconventional technology MD and NT. From the research conducted by Căpăţână et al., (2018), regarding the influence of soil tillage on soybean nodulation and yield, the experiment was placed on a chromic luvisol with a clay-loam texture, located at Moara Domnească Ilfov, results that the number of nodules/plant recorded in the plowing at $20 \mathrm{~cm}$ (23.8 nodules, the yield $2351 \mathrm{~kg} / \mathrm{ha}$ ), the highest value obtained in chisel plow at $20 \mathrm{~cm}$ ( 27.0 nodules, the yield $2260.7 \mathrm{~kg} / \mathrm{ha}$ ) and the lower values in disking at $10 \mathrm{~cm}$ (22.9 nodules, the yield 2044 $\mathrm{kg} / \mathrm{ha}$ ). Regarding the beneficial influence of the classical system on soybean yield, similar results were obtained in Poland by Gawęda et al., (2020), which showed that the yield was higher by $10.3 \%$ in the classic system (plowing), compared with no tillage system.

The green fertilizer + gulle 10 tons/ha $+\mathrm{N}_{40} \mathrm{P}_{40}$ has a major role in the nodules formation, weight and the soybean yield, difference between the control variant $(2354 \mathrm{~kg} / \mathrm{ha}$ with one fertilization at sowing) is $310 \mathrm{~kg} / \mathrm{ha}$ (influence significantly positive). Also the variant with green fertilizer $+\mathrm{N}_{40} \mathrm{P}_{40}$ presented the positively influences on the weight of root nodules (3.2 grams/plants) and contributes to the increase of yield with $176 \mathrm{~kg} / \mathrm{ha}$ comparative with control variant. The minimum tillage-disk variant (MD) and direct sowing (NT) led a poor development at nodules, weight and the soybean yield.

Table 3. The influence of the experimental factors on root nodules formation

\begin{tabular}{|c|c|c|c|c|c|c|c|}
\hline & The factors & number/pl & $\%$ & Difference & weight/grams/pl & $\%$ & Difference \\
\hline \multicolumn{8}{|c|}{ Tillage system (A) } \\
\hline $\mathrm{a}_{1}$ & Classic (CS) & $98.8^{\mathrm{Ct}}$ & 100 & 0.0 & $3.7^{\mathrm{Ct} .}$ & 100 & 0.00 \\
\hline$a_{2}$ & Minim chisel (MC) & 119 & 120 & $19.8 * *$ & 3.4 & 90.7 & -0.4 \\
\hline$a_{3}$ & Minim disk (MD) & 86.4 & 88 & $-12.4^{\mathrm{oo}}$ & 2.6 & 70 & $-1.1^{\mathrm{oo}}$ \\
\hline $\mathrm{a}_{4}$ & No tillage (NT) & 78.5 & 80 & $-20.3^{\mathrm{oo}}$ & 2.7 & 73.1 & $-1.0^{\mathrm{oo}}$ \\
\hline \multicolumn{2}{|c|}{$\begin{array}{l}\text { LSD (p 5\%) } \\
\text { LSD (p 1\%) } \\
\text { LSD (p 0.1\%) }\end{array}$} & & & $\begin{array}{l}5.5 \\
10 \\
22.1\end{array}$ & & & $\begin{array}{l}0.5 \\
0.9 \\
1.9\end{array}$ \\
\hline
\end{tabular}




\begin{tabular}{|c|c|c|c|c|c|c|c|}
\hline \multicolumn{8}{|c|}{ Fertilization (B) } \\
\hline $\mathrm{b}_{1}$ & $\mathrm{~N}_{40} \mathrm{P}_{40}$ & $93.4^{\mathrm{Ct}}$ & 100 & 0.0 & $2.8^{\mathrm{Ct}}$ & 100 & 0.0 \\
\hline $\mathrm{b}_{2}$ & gulle 5 tons $/ \mathrm{ha}+\mathrm{N}_{40} \mathrm{P}_{40}$ & 92.7 & 99.2 & 0.7 & 2.9 & 102.7 & 0.08 \\
\hline$b_{3}$ & green fertilizer $+\mathrm{N}_{40} \mathrm{P}_{40}$ & 96.3 & 103.1 & 2.9 & 3.2 & 114 & $0.4^{*}$ \\
\hline $\mathrm{b}_{4}$ & $\begin{array}{l}\text { green fertilizer }+ \text { gulle } \\
10 \text { tons } / \text { ha }+\mathrm{N}_{40} \mathrm{P}_{40}\end{array}$ & 115.1 & 123.2 & $21.7 * *$ & 3.5 & 121.5 & $0.6^{* * *}$ \\
\hline \multirow{3}{*}{\multicolumn{2}{|c|}{$\begin{array}{l}\text { LSD (p 5\%) } \\
\text { LSD (p 1\%) } \\
\text { LSD (p p.1\%) }\end{array}$}} & & & 9.1 & & & 0.3 \\
\hline & & & & 12.8 & & & 0.4 \\
\hline & & & & 18.1 & & & 0.6 \\
\hline \multicolumn{8}{|c|}{ Year $(C)$} \\
\hline $\mathrm{c}_{0}$ & Average & $95.5^{\mathrm{Ct}}$ & 100 & 0.0 & $3.1^{\mathrm{Ct}}$ & 100 & 0.0 \\
\hline $\mathrm{c}_{1}$ & 2018 & 94.6 & 99 & -0.9 & 3.2 & 102.8 & 0.09 \\
\hline $\mathrm{c}_{2}$ & 2019 & 93.7 & 98.1 & -1.8 & 2.9 & 93.1 & -0.21 \\
\hline $\mathrm{c}_{3}$ & 2020 & 98.3 & 102.9 & 2.8 & 3.2 & 104 & 0.13 \\
\hline \multicolumn{2}{|c|}{ LSD (p 5\%) } & \multicolumn{3}{|r|}{5.6} & & & 0.3 \\
\hline \multicolumn{2}{|c|}{ LSD (p 1\%) } & \multirow{2}{*}{\multicolumn{3}{|c|}{$\begin{array}{l}7.6 \\
10\end{array}$}} & & & 0.4 \\
\hline \multicolumn{2}{|c|}{$\operatorname{LSD}(p 0.1 \%)$} & & & & & & 0.5 \\
\hline
\end{tabular}

Table 4. The influence of the experimental factors on soybean yield, 2018-2020

\begin{tabular}{|c|c|c|c|c|}
\hline & The factor & $\begin{array}{c}\text { Yield } \\
(\mathrm{kg} / \mathrm{ha})\end{array}$ & $\begin{array}{l}\text { Relative } \\
\text { yield (\%) }\end{array}$ & Difference \\
\hline \multicolumn{5}{|c|}{ Tillage system (A) } \\
\hline $\mathrm{a}_{1}$ & Classic (CS) & 2656 & 100 & $0.0^{\mathrm{Ct}}$ \\
\hline $\mathrm{a}_{2}$ & Minim chisel (MC) & 2618 & 99 & -38 \\
\hline $\mathrm{a}_{3}$ & Minim disk (MD) & 2402 & 91 & $-254^{\circ 0}$ \\
\hline $\mathrm{a}_{4}$ & No tillage (NT) & 2314 & 87 & $-342^{000}$ \\
\hline \multicolumn{5}{|c|}{$\mathrm{LSD}(\mathrm{p} 5 \%)=76 \mathrm{~kg} / \mathrm{ha}, \mathrm{LSD}(\mathrm{p} 1 \%)=139 \mathrm{~kg} / \mathrm{ha}, \mathrm{LSD}(0.1 \%)=308 \mathrm{~kg} / \mathrm{ha}$} \\
\hline \multicolumn{5}{|c|}{ Fertilization (B) } \\
\hline $\mathrm{b}_{1}$ & $\mathrm{~N}_{40} \mathrm{P}_{40}$ at sowing & 2354 & 100 & $0.0^{\mathrm{Ct}}$ \\
\hline $\mathrm{b}_{2}$ & gulle 5 tons $/ \mathrm{ha}+\mathrm{N}_{40} \mathrm{P}_{40}$ & 2441 & 104 & 87 \\
\hline $\mathrm{b}_{3}$ & green fertilizer $+\mathrm{N}_{40} \mathrm{P}_{40}$ & 2531 & 108 & $176^{* *}$ \\
\hline $\mathrm{b}_{4}$ & green fertilizer + gulle 10 tons $/$ ha $+\mathrm{N}_{40} \mathrm{P}_{40}$ & 2664 & 113 & $310^{* * * *}$ \\
\hline \multicolumn{5}{|c|}{$\operatorname{LSD}(p 5 \%)=40 \mathrm{~kg} / \mathrm{ha}, \mathrm{LSD}(\mathrm{p} 1 \%)=76 \mathrm{~kg} / \mathrm{ha}, \mathrm{LSD}(\mathrm{p} 0.1 \%)=99 \mathrm{~kg} / \mathrm{ha}$} \\
\hline \multicolumn{5}{|c|}{ Year $(C)$} \\
\hline $\mathrm{c}_{0}$ & Average & 2497 & 100 & $0.0^{\mathrm{Ct}}$ \\
\hline $\mathrm{c}_{1}$ & 2018 & 2478 & 99 & -20 \\
\hline $\mathrm{c}_{2}$ & 2019 & 2416 & 97 & -81 \\
\hline$c_{3}$ & 2020 & 2599 & 104 & $101^{*}$ \\
\hline
\end{tabular}

\section{CONCLUSSION}

The highest value of 119 nodules/plant was recorded for the Teo TD variety cultivated in minim chisel system and the lowest value of 78.5 nodules/plant in no tillage (NT) system.

The number of nodules/weight/plant and the soybean yield was positive influenced by the organo-mineral fertilization.

The yield obtained was superior in classical system and very close in value to the yield obtained in the minimum tillage-chisel, the minor difference of only $38 \mathrm{~kg}$ suggesting the suitability of this system as well. 
Due to the pedological conditions from the experimental area, soybean crop is less suitable for cultivation under the directly sown system.

The minimum tillage system can be a successful alternative to the classical system in the hilly area of Transylvania and of course by practicing this system it is intended to reduce environmental pollution.

\section{ACKNOWLEDGEMENTS}

This work was supported by a grant of the Romanian Ministry of Research and Innovation PNCDI III, CCCDI-UEFISCDI, project PN-III-P1-2-PCCDI-2017-03-01/28 PCCDI/2019.

\section{REFERENCES}

CĂPĂȚÂNĂ, N., BOLOHAN, C., C. A, OPREA, MARIN, D.I. (2018). Influence of soil tillage systems and inoculation on soybean nodulation and yield. Scientific Papers, Series A, 61, 1, 46-52. CHEŢAN, F., CHEŢAN, C. (2014). Soybean cultivation in the conservative agriculture system and its role in environmental protection. National Symposium: The use of mineral and organo-mineral fertilizers in agriculture, October 7, 2013, Scientific papers Bucharest, AGRIS Publishing House Agricultural magazines SRL.

CHEŢAN, F., CHEŢAN, C., IGNEA, M., ŞIMON, A., DEAC, V., RUSU, T. (2014). Production results obtained from soybean, during 2007-2012 under the minimum tillage system at ARDS Turda. Annals INCDA Fundulea, Crop Agrotechnics, 82, 2015-286.

CHEŢAN, F., F., MUREŞANU, D., MALSCHI, C., CHEŢAN, L., SUCIU (2019). The influence of different tillage systems on the abundance of pests in soybean cultivation, in the conditions of the Transylvanian Plain. Romanian Journal for Plant Protection, 12, 23-30.

CVIJANOVIC, D., CVIJANOVIĆ, G. (1988). Display and assessment of the dynamic development of production and consumption of soybean in the world. Economics of agricultural, 35, 11-12, 687-697.

DOGAN, K., CELIK, I., GOK, M., COSKAN, A. (2011). Effect of different soil tillage methods on rhizobial nodulation, biomass and nitrogen content of second crop soybean. African Journal of Microbiology Research, 5, 20, 3186-3194.

GAWĘDA, D.A.N., HALINIARZ, M., WOŹNIAK, A. (2020). Yield and Economic Effectiveness of Soybean Grown Under Different Cropping Systems. International Journal of Plant Production, 14, 475-485.

GRIGORE, A.I., PETRE, A.A., GRIGORE, I., VLĂDUȚOIU, L., CRISTEA, M., MILIAN G., BIRIȘ, S.I. (2019). Considerations on the advantages of increasing the surfaces cultivated in an ecological system in Romania, compared to the classic-intensive cultivated surfaces. International Symposium Agricultural and Mechanical Engineering, 914-923.

GUŞ, P., CERNEA, S., RUSU, T., BOGDAN, I. (2004). Systems of seeding, fertilizing and conservating the crops. Ed. Risoprint Cluj-Napoca, 220p.

HÖFLICH, G., TAUSCHKE, M., KÜHN, G., WERNER, K., FRIELINGHAUS, M., HÖHN, W. (1999). Influence of long-term conservation tillage on soil and rhizosphere microorganisms. Biology and fertility of soils, 29, 1, 81-86.

IGNEA, M. (2017). 60 years of meteorological observations for the benefit of agricultural research, at ARDS Turda. Transylvanian Agriculture, 15-21.

KEYSER, H.H., LI, F. (1992). Potential for increasing biological nitrogen fixation in soybean. Plant Soil, 141, 119-135.

LI, R., CHEN, H., YANG, Z., YUAN S., ZHOU, H. (2020). Research status of soybean symbiosis nitrogen fixation. Oil Crop Science, 5, 6-10.

MARCHENKO, V.V., KOTKO, I.G., OPALKO, V.G. (2009). Technologies and technical means of sowing with minimal and zero processing. Agrarian engineering and equipment, 1, 6, 03, 20-28.

MARIN, D. I., RUSU, T., MIHALACHE, M., ILIE, L., NISTOR, E., BOLOHAN, C. (2015). Influence of soil tillage system upon the yield and energy balance of corn and wheat crops. Agrolife, 4, 2, 43-47. 
PEOPLES, M.B., BROCKWELL, J., HERRIDGE, D.F., ROCHESTER, I.J., ALVES, B.J.R., URQUIAGA, S., BODDEY, R.M., DAKORA, F.D., BHATTARAI, S., MASKEY, S.L., SAMPET, C., RERKASEM, B., KHAN, D.F., HAUGGAARD-NIELSEN H., JENSEN, E.S. (2009). The contributions of nitrogen-fixing crop legumes to the productivity of agricultural systems. Symbiosis, 48, 1-17.

POPOVIC, V., TATIC, M., SIKORA, V., IKANOVIC, J., DRAZIC, G., DJUKIC, V., MIHAILOVIC, B., FILIPOVIC, V., DOZET, G., JOVANOVIC, L.J., STEVANOVIC, P. (2016). Variability of yield and chemical composition in soybean genotypes grown under different agroecological conditions of Serbia. Romanian Agricultural Research, 33, 29-39.

POPOVIĆ, V., ŽIVANOVIĆ, L.J., KOLARIĆ, L.J., IKANOVIĆ, J., SIMIĆ, D., TATIĆ, M., STEVANOVIC, P. (2018). Effect of nitrogen fertilization on the yield components of soybean (Glycine max (L.) Merr). Journal of Institute of PKB Agroekonomik, 24, 1-2, 101-110.

PISANTE, M., STAGNARI, F. (2011). Agricoltura blu- la via Italiana dell'agricoltura conservativa, Manuale abbreviato. Associazione Italiana per la Gestione Agronomica e Conservativa del Suolo, Ancona, Italy, 1-51.

RUSU, T., GUS,, P. (2007). Soil compaction-processes and consequences. Ed. Risoprint Cluj-Napoca, 276.

RUSU, T., GUȘ, P., BOGDAN, I., MORARU, P.I., POP, A.I., CLAPA, D., MARIN, D.I., OROIAN I., POP, L.I. (2009). Implications of minimum tillage systems on sustainability of agricultural production and soil conservation. Journal of Food, Agriculture \& Environment, 7, 2, 335-338.

RUSU, T., MORARU, P.I., COSTE, C., CACOVEAN, H., CHEȚAN, F., CHEȚAN, C. (2014). Impact of climate change on climatic indicators in Transylvanian Plain, România. Journal of Food, Agriculture \& Environment, 12, 1, 469-473.

SABO, M., JUG, D., JUG, I. (2007). Effect of Reduced Tillage on Quality Traits of Soybean. Acta Agronomica, 55, 1, 83-88.

STEVANOVIC, P., POPOVIC, V., FILIPOVIĆ, V., TERZIĆ, D., RAJIČIĆ, V., SIMIĆ, D., TATIĆ, M., TABAKOVIĆ, M. (2016). Influence of fertilization at the nitrogen content and mass of the nodule of soybean (Glycine max (L.) Merr). Journal of Institute of PKB Agroekonomik, 23, 1-2, 119-128.

SUBRAMANIAN, S., SMITH, D.L.A., (2013). A proteomics approach to study soybean and its symbiont Bradyrhizobium japonicum -a review. INTECH, 3-30.

SZAJDAK, L.W., RUSU, T. (2016). Free sulfuric amino acids and rhodanese in soils under rye cropping and crop rotation. In: Bioactive Compounds in Agricultural Soils, Ed. Szajdak L.W. Springer International Publishing Switzerland, 91-122. doi: 10.1007/978-3-319-43107-9_4.

ŞTEFANIC, G., IRIMESCU, M., SPANU, I. (1997). Influence of mellowing mode and soil basic works on the soil vital state. Alternatives in Soil Tillage, 1, 123-130.

TOPA, D., AILINCĂI, C., RĂUŞ, L., ANTONESCU, M., JITĂREANU, G. (2012). Effect of tillage on soybean crop yield a physical properties on a chambic chernozem. Safety Health and Welfare in Agriculture and in Agro-food Systems, 597-603.

ULRICH, S., HOFMANN, B., TISCHER, S., CHRISTEN, O. (2006). Influence of tillage on soil quality in a long term trial in Germany. Soil Management for Sustainability, 110-116.

WOZNIAK, A., MAKARSKI, B., STEPNIOWSKA, A. (2014). Effect of tillage system and previous crop on grain yield, grain quality and weed infestation of durum wheat. Romanian Agricultural Research, 31, 1-9.

MESP (1987). Pedologic Studies Elaboration Metodology, Pedologic and Agrochemical Institute Bucharest, 1-3.

POLIFACT (2015). ANOVA and Duncan's test PC program for variant analyses made for completely randomized poly-factorial experiences.

SRTS (2012). Romanian System of Soil Taxonomy. Ed. Estfalia Bucharest 